\title{
La evolución de la agenda de seguridad Mexico-Estados Unidos
}

\author{
Security in Parts: The Evolution of the \\ Mexico-United States Security Agenda
}

\author{
Arturo Santa Cruz*
}

\section{Resumen}

En este artículo paso revista a la evolución de la agenda de seguridad Mexico-Estados Unidos desde que la relación entre ambos países se normalizó completamente, tomando la identidad estatal post-revolucionaria, el Nacionalismo Revolucionario, como la variable explicativa clave el proceso. En la primera sección conjeturo acerca de la construcción de la identidad y sus múltiples significados. En la segunda, analizo la identidad estatal post-revolucionaria como la base sobre la cual se estableció la relación de seguridad con su vecino del norte. En las siguientes tres secciones me centro en tres casos: la Segunda Guerra Mundial, la Cuba Comunista, y el tráfico de estupefacientes. Conforme la identidad de Mexico ha evolucionado, una especie de «seguridad en partes» parece estar emergiendo en esta díada norteamericana.

Palabras clave: Mexico, Estados Unidos, seguridad, idea del Hemisferio Occidental, Iniciativa Mérida

\section{Abstract}

I review the evolution of the U.S.-Mexico security agenda since the relationship between the two countries became fully normalized, taking the post-revolutionary state identity, Revolutionary Nationalism, as the key explanatory factor in the process. In the first section I elaborate on the

Director, Centro de Estudios sobre América del Norte, Universidad de Guadalajara, arturosc@hotmail.com

Recibido el 12 de marzo de 2014; aceptado el 20 de mayo de 2014. 
construction of identity and its multifaceted meanings. The second looks at Mexico's post-revolutionary identity as the bedrock of the country's security relationship with its northern neighbour. In the following three I look at three cases: World War II, Communist Cuba, and drug trafficking. As Mexico's identity as evolved, a sort of 'security in parts' in this North American dyad seems to be emerging.

KeYwords: Mexico, United States, security, identity, Western Hemisphere Idea, Mérida Initiative 
Mexico's security relationship with the United States has historically been characterised by distance-geographical contiguity between the two countries notwithstanding. But it was precisely this proximity, or rather the opportunity this closeness meant for the stronger party to take over part of the weaker one's territory in the nineteenth century, which set the tone for the distal approach on security affairs during most of the twentieth century. I say during most of the twentieth century because during the last years of the Porfirio Díaz regime (1876-1910) there was a rapprochement on security matters. ${ }^{1}$ However, over the last century there was one particular event of an internal nature that would go farther in explaining Mexico's resilient attitude in security affairs toward its northern neighbour: the 1910-1920 revolution.

The Revolution created a new sense of national purpose and state identity, and with it a new understanding of its sovereignty. The post-revolutionary identity's defining characteristic as it regards the outside world, and particularly the U.S., was keeping the northern neighbour at arms length-except in critical times-in order to protect its sovereignty. Thus, during World War II (WWII) there was bilateral cooperation on security matters - but even then Mexico's was rather aloof. After the extra-continental threat disappeared, so

1 As in the 1907 peace treaty -convention- regarding Central America and in the sending of Mexican military personnel for training in US academies. did Mexico's cooperation with Washington on security affairs. However, there were also some lesser threats, both to US interests and particularly to the post-revolutionary political regime, which made cooperation possible. In these matters, such as the perceived ' $\mathrm{Cu}$ ban Communist threat', Mexico City and Washington shared a basic interest and, accordingly, cooperated-even if this was done in a most subdued fashion. Of a different, and at the same time more complex and fundamental nature, drug trafficking became a central concern (first due to US pressure and later chiefly to the threat it represented internally) of the bilateral security agenda. It would actually be this composite item in the bilateral security agenda, as crystallised in the 2007 Mérida Initiative, that would lead to what might amount to a novel understanding of Mexico's security relationship with its northern neighbour.

In this article I review the evolution of the U.S.-Mexico security agenda since the relationship between the two countries became fully normalised, in the 1940s, taking the post-revolutionary state identity, Revolutionary Nationalism, as the key explanatory factor in the process. The first section is mostly analytical; in it, I elaborate on the construction of identity and its multifaceted meanings. In the second, taking a more historical stance, I look at Mexico's post-revolutionary identity as the bedrock of the country's security relationship with its northern neighbour. In the following three sections I look 
at the above mentioned cases: WWII, Communist Cuba, and drug trafficking, in that order. While discrete, as a whole the three cases point to the broader context that has served as the foundation for the sporadic bilateral cooperation on security matters. Resting on a minimalist common understanding of security, whilst Mexico's Revolutionary Nationalism as state identity unfolded, various elements seem to have started adding up-and the construction of a 'security in parts' in this North-American dyad seems to be emerging.

\section{SOVEREIGNTY AS IDENTITY}

It has commonly been observed that the modern state system is a bifurcate one. It is composed of international ordering principles on the one hand, and of distinctive political units on the other. The divide, however, is not clearcut. Thus, for instance, one of the system's ordering principles, sovereignty, is shot through and through by unit-level features. It is a structural intervening variable whose content, at the state level, is filled by the projection of domestic purpose. Since sovereignty is an internationally recognised status, it is only logical that states seek to imbue it with their national object. It is not that the principle as such is directly concerned with it, that is, with the individuality of the states, but rather that it sets the stage for them to provide its content while 'doing' their sovereignty (Werner and De Wilde 2001, 297; Wendt 1999,
182-183; McSweeney 1999, 165).Thus, states' patterns of authority and culture produce a particular sovereign-identity that is in turn projected onto the international system.

Identity as a social category contains two dimensions, which vary with time: its content and the degree to which it is contested. The purpose of the collectivity, its worldview, is part of the first dimension. The second refers to the extent to which the content of identity is accepted by members of the group (Abdelal et al. 2006, 696). Whereas the contentious nature of identity points to its fluidity, its substantive component directs us in the opposite direction: its (relative) permanence. Once established, identity creates interests and limits the range of choice-not 'everything goes with a given identity (Katzenstein 1996, 30). ${ }^{2}$ This is not to suggest that only one, overarching identity existsstate identities often vary according to the issue area in question. However, not all identities carry the same weight nor have the same endurance. Some have a greater prominence and resilience than others-and changing these identities, like altering any tradition or customary practice, is not easily done(Legro 2009, 44). But even these heavier, more salient identities do change-and it is easier to grasp this mutation by disaggregating

To say that identity stands analytically apart from interests and that on many occasions precedes them is not to postulate a clear-cut division between them, or to privilege an ethereal concept over a more «concrete» one. 
them, as I do here with regard to the security component of Mexico's sovereign identity vis-à-vis the United States.

The multifaceted practice of sovereignty endows the term with multiple meanings, depending on time and context. Thus, for instance, whereas 'economic sovereignty' has been crucial for some countries in some periods, it has ceased being considered so in others. To a large extent, the multivocal and changing understanding of sovereignty ows to its being part of a bipartite normative structure. The twofold nature of international politics thus points to the one important element: identity is constructed on two fronts (McSweeney 1999, 160). That is, states' identities are contested and defined by political processes taking place both inside their borders-by the contestation among sub-national groups-and outside-by the interaction states have with other states and other actors in the international arena. Hence, the successful construction of sovereignty requires achieving cohesion internally and distinctiveness and respect internationally-an eminently political process (Subotic 2011, 312; Kowert 2007, 5; Werner 2001, 308).

Moreover, identity is relational. Selfdefinition depends in part on others, to whom the self is constantly contrasting and comparing (Smith 1998, 181). However, 'others' are not static, nor do actors have 'objective' knowledge about them. Hence, one's understanding of others is predicated not only on the moment a specific interaction takes place, but also on both the historical baggage of the relationship and the perception of self in the mirror of others.

That is why not only identity, but also the construction of national narratives is a deeply political process-also anchored in history. Founding myths and historical watersheds intermingle and vie for political salience in this undertaking, in which collective memory plays a fundamental role. Without collective memory both the solidarity anchored in the past and the notion of a common future that imbues the state with a sense of purpose would not coalesce to form the identity any collectivity needs to function (Kratochwil 2008, 455; Abdelal et al. 2006, 699). Traumatic events, such as civil wars, genocide or foreign invasions, are particularly salient in this respect. They create a culture of memory that survives in the collective imaginary and oftentimes institutionalises it. ${ }^{3}$

Relatedly, collective memories are instrumental in limiting the range of what is politically feasible by creating taboos. Accordingly, the more hegemonic the collective memory on a historical event becomes, that is, the closest it is identified with the orthodoxy, the more discursive power it enjoys in shaping the interests and identities of society. That is why the construction of a national narrative is actually a political process (Langenbacher 2010,13, 27, 32-33; Fossaert in Gall 2004, 223).

3 As in Mexico's National Museum of Interventions. 
Nationalism is a particularly salient identity of nation-states. It is in part the product of cultural innovations-a fact that is often neglected in international relations literature (Cf. Waltz 1979. Breuilly 1985, 67). In the case at hand, the brand of nationalism that came out of Mexico's Revolution was the direct effect of the new concept of collectivity produced by the armed conflict. It was only at this point that Mexico started to posses and display both national coherence as well as a distinct identity in the international system. It is important to note the continuum between the domestic and the international components on identity: it was only by virtue of the internal coherence as expressed in the new, post-revolutionary identity that Mexico's relationship with the United States would radically change (Kowert 2007, 1, 6-7). The two facets of this identity were a new nationhood-the domestic, purposive content of revolutionary nationalism - and a new statehood-the new conception of state sovereignty contained in revolutionary nationalism and projected internationally-particularly in the security arena, as discussed below (Jepperson et al. 1996, 59). ${ }^{4}$

\footnotetext{
Although national identity and state identity can be analytically separated, and in some cases it is useful to do so, both terms are used interchangeably. See Jefferson 1996; Fearon 1999. James D. Fearon, "What is identity (as we now use the word)?», (1999).
}

\section{REVOLUTIONARY NATIONALISM}

\section{AS STATE IDENTITY}

As noted, Mexico's foreign policy doctrine, its practice, and the way the country understood and approached the United States since the early 1920's are the direct outcome of the Revolution and, more specifically, of the identity it produced: revolutionary nationalism.

With the armed struggle as the 'touchstone of national identity', revolutionary nationalism became the discourse that more fully articulated the new national project (Comisión para el futuro de las relaciones Mexico-Estados Unidos, 1988, 15). Basically, the revolutionary myth was about the idea that state sovereignty was coterminous with a powerful state, one capable of delivering on the promises contained in the 1917 Constitution (Knight 2009, 228; Erfani 1995, 58). Along with the myth of the Revolution emerged a new understanding of the nation-as well as a more inclusive and forceful national identity (Lopez 2010, 14, 2). It was precisely this new identity that served as the basis of the new nationalism.

In the domestic realm the character of the new state included both material and ideational factors. Thus, key elements were control of natural resources and nationalisations, but also exaltation of national identity, particularly of its indigenous component (Bartra 1989, 199). In the external realm, revolutionary nationalism meant distrust of great powers-particularly 
of the northern neighbour. This was so for historical reasons, particularly the memory of Mexico's dismemberment by the United States (Zorrilla 1965, 508; Ojeda 2006, 111). But there was also a forward-looking factor at work: the need to preserve the country's distinctiveness vis-à-vis its northern neighbour (Meyer 2000, 911). In this regard, a significant resource was the cultural revolution that took place during the revolutionary phase (19101920) and its aftermath; as Alan Knight has noted, it 'allowed Mexico to form a national identity [and] gave Mexico the necessary discursive tools to resist US cultural hegemony'(Knight 2000, 45; see also Monsiváis, 1976, 1382)..$^{5}$ This new identity meant a relatively stable-if malleable over time-understanding of both Mexico as a nation and the country's most important interlocutor: the United States. With the historical memory and the intent to preserve Mexico's values and interests, the post-revolutionary regime's foreign policy doctrine factored in the presence

5 Thus, for instance, in 1972 President Echeverría noted that Mexico «struggles to affirm its identity,» and the following year reiterated that, in relations with the United States, "we aim to preserve our sovereignty and increase our cultural personality over any other achievement of material reward» (Tello 1975,22, 256.).Similarly, de la Madrid's Foreign Minister Bernardo Sepúlveda later commented on the country's need of «reaffirming [its] autonomy, identity and personality» for which foreign policy was instrumental (Sepúlveda 1994,39; Knight 2000, 45). see also Monsiváis 1976, 1382). of the United States across the northern border. Having a neighbour that declared its own right of tutelage over the entire western hemisphere was indeed an effective incentive to formulate a defensive foreign policy doctrine, one that emphasised political independence in the international arena (Sepúlveda Amor, 1994, 18 and 37; Ojeda 2006, 126-127).

The new national identity contained a renewed sense of purpose and an innovative national project. revolutionary-nationalism became 'the paraphrasis of the Monroe doctrine: Mexico for the Mexicans'(Herrera-Lasso and Tello-Peón 2011, 271). But there was more. The revalorisation of the Indian component of the nation meant that the country assumed itself as a backward society. This self-understanding would profoundly shape the path Mexico would follow both in domestic and international affairs. In the former, for instance, with the state's support of a land tenure system that supposedly corresponded to pre-colonial traditions, and in the latter with the often hermit-like position the country would assume in the international scene (Lomnitz 2010; Bartra 1991, 2; Ojeda 1966, 128).

The new identity also had a substantial effect on the security apparatus and on the country's international practice on diplomatic affairs in general and security matters in particular. The armed forces that emerged from the internecine war not only became an integral part of the new state: they also adopted 
Revolutionary Nationalism as their own identity and discourse. Thus, military doctrine was from early on imbued with both a mythical narrative of the revolution and deep suspicion of the United States (Downie 2011, 7). Accordingly, in the decades following the revolution Mexico adopted largely introspective grand strategy and national security doctrines. It appeared that only the most salient incentives offered by the international state system were not rejected by the post-revolutionary leadership in its approach of scant involvement in international security affairs. The objective was not autarky, but rather the buttressing of the new state. This in turn would contribute to strengthen Mexico's position on security affairs vis-à-vis the United States. As Miguel Alemán noted in his acceptance speech as the governing party's presidential candidate in 1946, Mexico had won 'a place of honor in the concert of nations' thanks to the achievements of the post-revolutionary regime, as reflected in its diplomatic practice $(E l$ Informador 1946). Four decades later, President Miguel de la Madrid (19821988) referred to Mexico's foreign doctrine as 'synthesis and instrument of our Revolutionary Nationalism (Concepción Montiel 2006, 306).

Revolutionary nationalism, however, included a principled component that set the stage for collaboration on security affairs with the United States: the Western Hemisphere Idea (WHI) (Whitaker 1954; Santa Cruz, 2005). The WHI refers the New World's normative structure; first stated in the early nineteenth century by Thomas Jefferson in his farewell address, it sets the countries of the western hemisphere apart from European ones. The WHI is imbued with a set of principles, such as the representative form of government of its constitutive units, noninterference in the domestic affairs of states, and a purported community of interests among its members. Thus, for instance, when the Monroe Doctrine was proclaimed in 1823, Mexican President Guadalupe Victoria considered it a 'memorable promise' on Washington's part(Victoria 1986, 299). Along the same lines, more than a century later President Alemán referred to the United States as a 'strong and prosperous' country that struggled with the 'immense responsibilities' it had to bear 'under the moral sign of democracy' (Archivo Histórico Diplomático 1947). Thus, Mexico came to recognise some fundamental US interests and its regional ascendancy, as well as the complementarity of interests between the two countries in some issue areas. Revolutionary nationalism, however, precluded open (and systematic) recognition of this fact. That is why there was no talk of any sort of common identity between the two countries, or of Mexico receiving a different treatment from its northern neighbour. If there has been a special relationship between Mexico and the United States, as many authors argue, it has been one that has not dared speak its name-for identity 
reasons ${ }^{6}$. Mexico thus kept a nationalist discourse, a formally democratic regime, and a mostly independent foreign policy, while guaranteeing the United States a stable and non-communist neighbour ${ }^{7}$.

\section{WORLD WAR II}

Mexico's partnership with the United States during WWII evinces both the normative underpinnings of the WHI as well as the importance of Revolutionary Nationalism as state identity. By the late 1930s and early 1940s there was no popular or elite perception that the war represented an existential threat to Mexico. However, the country's leadership was well aware that the new international conflict meant not only a first-order menace to Washington but also to the hemisphere's values. Furthermore, the Mexican government saw in WWII a good opportunity to link its cooperation to outstanding issues in the bilateral agenda, such as debt and oil expropriation settlements (Torres 1979 24, 32, 37). Thus, the administrations of presidents Lázaro Cárdenas (1934-1940) and Manuel

6 Bow, Brian and Arturo Santa Cruz. "Power, Identity and Special Relationship: The US-Canada and US-Mexico Relationships in Historical and Comparative Perspective». Paper prepared of the 2010 American Political Science Association meeting. Washington, D.C., September 2-5.

7 Santa Cruz, Arturo (2012). MexicoUnited State Relations: The Semantics of Sovereignty. New York, Routledge.
Ávila Camacho (1940-1946) struggled against the deep-rooted popular antiAmericanism-which in this context was mixed with widespread sympathy for Germany, considered the underdog-in order to get support for siding with United States in the war's effort (Zorrilla 1965, 485, Torres 1979, 65).

It was clear that on this juncture both interests and values of Mexico and the United States converged(Velasco Márquez 2006, 92). Tellingly, however, Mexican authorities chose to emphasise the partnership in terms of the defence of the broader, hemispheric realmnot so much as a joint Mexico-United States endeavour. This of course had to do with the just-mentioned pervasive anti-American feeling. Thus, in the Summer of 1941 President Ávila Camacho (1940-1946) explained to the Mexican people:

it would be wrong to think that in the current state of affairs, the destiny of one of the American nations could be indefinitely isolated from that of the rest. Geographically, historically and logically we all constitute a democratic unit that dictatorial forces will attempt, no doubt, to disarticulate in order to obtain a victory that in the short or medium run would imply the disappearance of the principles on which rests our existence as sovereign and free peoples (Torres 1979, 71-72).

Later that same year Mexico's ambassador to Washington was at pains to point out that Mexico's cooperation with its northern neighbour had as its ultimate objective 'the defense of the 
American Continent'(Mexico-United States 1941, 201). Similarly, in 1942 Foreign Affairs Minister Ezequiel Padilla rejected the involvement of US army personnel in defending Mexican facilities, as 'it could have extremely unfavourable political and moral effects in Mexico's army and population at large.'(Security. FF17B 1942, 2). And still three years later, when honouring the members of the air 201 ${ }^{\text {st }}$ Fighter Squadron on their return from the $\mathrm{Pa}$ cific front, where they had seen combat under the command of US General Mac Arthur, the Mexican representative emphasised their contribution to the independence and freedom of the western hemisphere, 'from Alaska to Cape Horn. ${ }^{8}$

However, cooperation on security matters took place fundamentally at the bilateral, Mexico-U.S. level. Thus, in July 1941, both countries subscribed an agreement by which Mexico accepted the prohibition of exporting strategic materials, and some months later it signed the Convention on Claims Settlements, with which it paid back the debt owed due to land expropriation. As President Ávila Camacho stated when the U.S. participation in WWII was immanent: 'In the difficulties of coming days, the United States may be assured

8 In contrast, the congratulatory notes to the Mexican squadron from President Truman, Chief of Staff of the Army Marshall, and Supreme Commander of the Southwest Pacific Area Mac Arthur all explicitly refer to the joint US-Mexican effort (Secretaría de la Defensa Nacional, 1979). of the sincerity of our solidarity'(Archivo Histórico Diplomático 1941).So, in February 1942 the Joint Mexico-United States Defense Commission, among whose objectives were the elaboration of plans 'for the defense of Mexico and adjacent areas of the United States', was formed (Historic Diplomatic Archives 1942; Woolley and Peters n.d.).

While the Mexican contribution to the war effort would be largely symbolic-only the above-mentioned squadron saw action-the decision by Ávila Camacho's government held great political value. Mexico had indeed become strategic in US policy and its attitude only helped to cement the WHI(Haglund 1984). As the Mexican ambassador in Washington, Francisco Castillo Nájera, would say: 'The most significant part of the role played by Mexico in the war is that for the first time in history Mexico is united in objectives and ideals with the U.S.'(Diplomatic Historical Archive n.d). During the war Mexico did allow the United States access to its ports (maritime and air), as well as the construction of radar stations(Benítez Manaut 1998, 63 and 64; González and Haggard 1998, 306). Thus, by the war's end it had become clear that, when push comes to shove, Mexico was willing to collaborate with the United States (Zorilla 1965, 508).

As the Cold War became more stable and the economies of both countries increasingly integrated, it became obvious that a harmonious relationship was in the interests of both nations. The 
collaborative military aspect, however, would end with the war (Cope 1997, 239; Torres 1979, 150). Thus, in 1948, when the urgency of obtaining training camps for the US Marines had passed, Mexico revoked the permission it had granted the U.S. in September 1943 (U. S. Department of State 1972, 645).Along the same lines, Mexico was far from being an enthusiastic promoter of the 1948 Inter-American Treaty of Reciprocal Assistance, because it was considered an instrument for US power. Mexican leaders argued in Washington that their country was 'different from other Latin American countries'-and that it must refuse to contribute armed forces in defence of the hemisphere(U. S. Department of State 1983, 1327). ${ }^{9}$ By the mid 1940s the military establishment in the U.S. came to accept the idea of 'Mexican isolationism'-thus confirming what seemed, if not an unspoken special relationship, at least a tacit agreement (Paz 1998, 231). In general, Mexicós stance in international affairs during the Cold War was, in the words of one of the practitioners, 'one of mistrust and partial disinterest, and its foreign policy is mostly defensive and anti-interventionist'(Castañeda 1969, $155) .{ }^{10}$

9 This did not mean, of course, that all military cooperation ceased; in early 1960 there was already a discrete but growing training programme in effect for Mexican military members in the U.S. (Archives of the State Department 1961b, 3).

10 As John Cope would note: «U.S.-Mexico relations in defense issues have followed different rules and methods compared to those of Washington and Ottawa or those
Indeed, a declassified document the US embassy in Mexico sent in February 1961 to the State Department noted with some resignation: 'by remaining cool to the U.S. responsibilities in the prolonged crisis of the Cold War, Mexico feels pride in its sovereign independence'(Archives of the State Department 1961a, 6).Even after the North American Free Trade Agreement came into effect in 1994, when it had become clear that unipolarity was clearly not a fleeting moment in world politics, Mexico did not substantially change its foreign or security policies (Curzio 2007, 112). As Michael Dziedzic pointed out at the time: 'defense policy in Mexico responds principally to domestic stimuli... While global order has undergone a thorough retrofit, the country's defense policy has not' (Dziedzic 1994, 110).

\section{Communism-CubA}

For Mexico the relationship with Communist Cuba was part of a triangle. One vertex represented the nonintervention principle: revolutionary nationalism dictated that Tlatelolco take a maximalist stand regarding the right of Havana on domestic affairs; the second had to do with the country's relationship with the United States: for both normative and pragmatic reasons, Mexico City could not antagonise Washington on such a fundamental

of Washington and the rest of Latin America» (Cope 1997, 235). 
matter as the alleged struggle against Communism in the hemisphere; finally, the third vertex referred to the postrevolutionary regime's own interests: keeping a check on Cuban activities in the country would avoid potential political instability. As suggested, post-revolutionary Mexico held a mutually beneficial—if only tacit-agreement with its northern neighbour: in exchange for its right to dissent on secondary issues, Mexico would assist their powerful neighbour in fundamental matters (Ojeda 2006, 120). Thus, in 1955 President Adolfo Ruiz Cortines (1952-1958) let the US ambassador know that if the Communists lead the US government into a confrontation, Mexico would be 'definitely' on Washington's side(State Department Archives 1955, 2). Again, in March of the following year, the Mexican president informed President Dwight Eisenhower that he agreed with him in that Soviet embassies were centres of subversion and spying, and should therefore be under surveillance; indeed, his administration already practiced such measures, for domestic and international reasonsArchives of the U.S. State Department 1956, 3).

Similarly, and returning to the Cuba-Mexico.U.S. triangle, a few weeks before the 1962 VIII Meeting of Consultation of the Organization of American States (OAS) Foreign Ministers held in Punta del Este (in which Mexico cast the only dissenting vote on the issue of expelling Cuba from the regional organisation),
President Adolfo López Mateos told US Ambassador Thomas Mann that he personally did not sympathise at all with the Castro regime but that the defence of the non-intervention principle was paramount (Rojas y Covarrubias 2011, 138-139). As Mexican diplomats had informed their US counterparts the year after the triumphant entry of the rebels in Havana, Mexico was even more concerned than they were about the increase of Soviet influence in Cuba (New York Times 1960). Less noted than its voting position at Punta del Este, though, is Mexico's Foreign Affairs Minister's speech at the session, which is profoundly revealing of Mexico's appraisal of Communist Cuba. It is worth quoting a couple of paragraphs at length:

For the first time in the history of the Americas, one of our governments clearly declares that it upholds an ideology and a political system that is totally divorced from the policies that have been the common denominator of institutions of all peoples of the New World. Even if, on more than one occasion, some of our governments were not faithful to the principles and the norms of representative democracy, never had any of them had declared to uphold a different political philosophy.

It thus seems unquestionable that there is a radical incompatibility between belonging to the Organization of American States and upholding a Marxist-Leninist political creed, as it would also be with the upholding of an absolutist monarchical one. With the same energy with which we 
Arturo Santa Cruz • La evolución de la agenda de seguridad México-Estados Unidos

defend the non-intervention principle for all the peoples, and therefore that of the Cuban people, we assert that being a member of our organization is incompatible with the adoption of a governmental regime whose characteristics are not the ones of representative democracies(Manuel Tello in Rojas and Covarrubias 2011, 140).

Thus, at a Summit meeting held in July 1962 by presidents Kennedy and López Mateos, ambassador Manuel Tello noted that his country had been the first one to openly adhere to the doctrine regarding the incompatibility of the Cuban political regime and the Inter-American system (Archives of the Department of the State 1962). In the accompanying communiqué issued at the end of the summit, referring to both Cuba and the Soviet Union, both leaders stated their commitment 'To oppose totalitarian institutions and activities which are incompatible with the democratic principles they uphold'(New York Times 1962).

A couple of years later President Gustavo Díaz Ordaz (1964-1970) would reiterate his government's alignment with Washington. During a meeting with President Lyndon B. Johnson at his ranch in Texas, the Mexican dignitary assured his counterpart that he 'could be absolutely sure that when the chips were really down, Mexico would be unequivocally by its side'(LBJ Library Archives 1964a, 3). Díaz Ordaz articulated what had been only a tacit agreement: 'There was a considerable advantage when the is- sues at stake were not great if Mexico could continue to demonstrate its political independence and divergence on relatively minor issues' (The Nixon Tapes N.D.).

An affinity was found between the U.S. and Mexico regarding socialism in the hemisphere, attended by close collaboration. Consequently, in 1964 Secretary of State Dean Rusk would point out that Mexico had helped the U.S to control Castro, although the country was very 'sensitive' about publicity regarding such cooperation(National Security Archive 1964, 21). Mexico also restricted travel to the island-something the U.S. appreciated (LBJ Library Archives 1964b). Collaboration was not limited to such restrictions, but also included, for instance, photographing each traveller arriving from Cuba (State Department Archives 1965).

Maintenance of relations between Mexico and Cuba obeyed in part to an informal agreement with Washington regarding the advisability of having a member of the OAS with a 'foot in the door' that could be useful to US interests (National Security Archive 1967, 14).Thus, in 1967 the Mexican ambassador to Cuba, Miguel Covián Perez, agreed to provide the US embassy in Mexico with information regarding relevant matters, not only via the Mexican ambassador Antonio Carrillo Flores, but also via 'informal and unofficial contacts' (The Nixon Tapes). As a former US national security advisor would say, 'the rule [between the United States and Mexico] was, "you have 
diplomatic relationships with Cuba, but you let us crack everything the Cubans do in Mexico»'(Interview with Pastor 2008).

However, as suggested, beyond cooperation with its the powerful northern neighbour, the Mexican government had its own reasons to play a double game in its relations with Cuba. As Covián Pérez's predecessor in Havana wrote to Secretary Carrillo Flores: 'Commander Raul Castro has always supported the activities guerrilla groups operate in Central and South America'(Historic Diplomatic Archives 1967). Even the apparently anti-American President Luis Echeverría (1970-1976) was aware of the importance of Mexico's double game in its relations with Havana. ${ }^{11}$ For example, in a meeting with Richard Nixon, he explained beforehand the meaning of the speech he would deliver at the United Nations: it was necessary to ratify the Mexican position regarding the role of

11 According to the Washington Post journalist Jefferson Morley in his book about Winston Scott, who headed CIA operations in Mexico from 1956 to 1969, López Mateos, Díaz Ordaz, and Echeverría collaborated with the agency-before taking office as presidents-fundamentally sharing information on Cuba as agents on hire. (cf. Morley 2008)). In an interview with the State Department historian, Marc Susser, and his two Mexico specialists, Halbert Jones and Douglas Kraft, carried out on 4 Aug. 2008 in Washington, the author asked about the veracity of Morley's information; the answer obtained was that they could neither deny nor confirm it. the Third World, since unless I carry the flag in Latin America, Castro Ruz will capture it'. President Echeverría clarified that for Mexico 'Cuba is a Soviet base in every sense of the term, military and ideological, and we have it just under our nose,' and that his nation's aim was to 'contribute, more than any other Latin American country, to taking the flag of progress out of their hands'(National Security Archive1972). As Mexico's post-revolutionary identity demanded, the three vertexes of the triangle Communist Cuba represented to the country were kept in balance.

\section{DRUg TRAFFICKING}

Although drug smuggling from Mexico to the United States had been a contentious issue since the 1920 s, until the mid-1980s it had been managed in a relatively successful and cooperative fashion. ${ }^{12}$ But the situation changed around that time. As a result of the closure of the Caribbean routes of cocaine traffickers from Colombia to the U.S. in the early 1980s, Mexico turned into a drug corridor. This phenomenon provoked a series of changes in the modus vivendi of those involved in the world of drugs in Mexico. Drug lords began dividing up the country into zones of control, which no longer followed the

12 As former Mexican Foreign Affairs Minister Bernardo Sepúlveda would note, drug smuggling did not use to be a foreign policy or national security matter (Sepúlveda Amor 1994) 
terms of the tacit understanding that had prevailed for decades between them and Mexican authorities. By the mideighties Mexico was a principal supplier of drugs in the United States: it held about 40 per cent of the heroin market and 30 per cent of marijuana(Serrano 2007, 268). From Washington's point of view, the situation was to be blamed on Mexico's feeble commitment to the fight against drugs.

Further aggravating the situation, in February 1985 DEA agent Enrique Camarena Salazar, was kidnapped and later murdered in Guadalajara. Camarena ran Operation Padrino, a joint operative whose goal was arresting heroin and cocaine traffickers. The administration of President de la Madrid's was surprised by the event and reacted in an inconvenient manner-which was taken by the US government as evidence of the indolence and corruption of Mexican officials (Castañeda y Pastor 1989, 333). Secretary of State George Shultz declared: 'Our level of tolerance has been exceeded by these events, and they [Mexican officials] know that' (New York Times 1985).

As a result of this unfortunate incident, Washington hardened its position on the drug war and in its dealings with Mexico. Initially, Camarena's murder resulted in the DEA's Operation Legend, aimed at bringing before US courts those believed responsible for Camarena's murder (Toro 1998, 335). In addition, in 1986 the Law Against Drug Abuse was passed, and included punitive measures against Mexico, such as the withdrawal of resources (a million dollars of assistance in the drug war) if Mexico did not provide information on the progress of the Camarena murder case(Treverton 1989, 277). That same year the US Congress institutionalised the annual certification process on cooperation in the combat against drug trade, applied to countries working with the United States. Countries found to be, according to reports received by the US President, participating in the production or traffic of drugs, would not be certified and would be sanctioned by, for example, the suspension of assistance via US programmes. Moreover, one measure that was apparently domestically oriented, contributed to further complicate bilateral relations: National Security Directive 221, adopted in April of 1986 by President Ronald Reagan, considered drug trade to be a threat to national security(Ruiz-Cabañas 1998, 111 and 112). The implication was clear: Mexico, as a source of narcotics, became a threat to US national security. The signals being sent by Washington were far from flattering: in 1988, for example, the Department of State would point out in its report to Congress that 'the corruption in higher levels of the Mexican government continues to be the most serious obstacle to effective cooperation with Mexico regarding drug trade' (In Castañeda and Pastor 1989, 336; El Universal 2000).

Mexico reacted accordingly. In 1987 the de la Madrid administration defined drug trafficking as a 'state mat- 
ter' that constituted a national security threat. Similarly, Carlos Salinas's (19881994) and Ernesto Zedillo's (19942000) administrations considered drug smuggling a menace to national security(Ruíz-Cabañas 1998). The latter went further than the others in that it declared that drug traffic was the main threat to Mexican national security-and the battle against drug trafficking became part of Mexico's foreign policy(Andreas 1998, 161; Toro 1998, 16). In 1996 Zedillo's government proposed to that of President William Clinton the establishment of a High Level Contact Group on the matter of drug control (Bárcena Caqui 2003, 24). In 1997 a joint document, the 'U.S.-Mexico Bi-National Drug Threat Assessment' identified drug traffic as a 'common threat' and established an 'alliance' to fight against drug use and trafficking (González González 2003, 263). That same year both leaders issued the Presidential Declaration on Anti-Drug Cooperation and an extradition protocol was agreed upon. In 1998 Mexico and the U.S. adopted a Bilateral Strategy for Cooperation against Drugs. Beyond documents and pronouncements, bilateral collaboration enjoyed its best period in the late 1990s.

However, the deepening of relations in the struggle against drug trade clearly did not lack setbacks. One very illustrative case follows: in February 1997 General Jesús Gutiérrez Rebollo, director of the National Institute to Combat Drugs, was arrested due to his association with the leader of the Juárez cartel, Amado Carrillo Fuentes(Schulz 1997, 18). Gutiérrez Rebollo's US counterpart, anti-drug Czar and also (retired) General, Barry McCaffrey, had described him as 'a serious soldier, a person of absolute and unquestionable integrity'. Just one week before he was arrested, the Mexican General had visited Washington, where he had received a detailed summary of classified information regarding US antinarcotics strategies(Schulz 1997, 18 and 19).

Another setback in the strengthening of bilateral cooperation in the struggle against drugs took place a year later. In May 1998, Operation Casablanca was uncovered, a US sting, which-without the Mexican government's consent-lasted three and half years and employed undercover investigation, investigation of money laundering in the U.S. and Mexico. The initial result of the operation was the decommissioning or freezing of US $\$ 157$ million, and the arrest of 22 Mexican bank officials (Enciso 2009, 235). Casablanca was a flagrant violation not only of Mexican sovereignty and the bilateral agreements shared by the two countries, but also of the climate of trust that had been established by both countries' officials. Despite the commotion caused by the discovery of the Mexican anti-drug Czar's illicit activities and detention, eight months later, at a Senate hearing, McCaffrey would say: 'In the last 2 years the level of cooperation on the drug issue has been phenomenal, to the point that it 
would clearly... rank as one of the most dramatic transformations I have seen in the region in the last 30 years'.» (Senate Foreign Relations Committee 1997).

By now revolutionary nationalism as state identity was on its way out. Thus, for instance, the Zedillo administration's six-year plan did not even mention either it or the 1910 Revolution, as had been ordinarily been done since the 1930s. There were, however, a few references to Mexican nationalism as a living force in Zedillo's sixyear plan; it notes, for instance, that it "guides our conduct abroad and sustains our future.» (Poder Ejecutivo Federal 1995).

Furthrermore, there was a sharp discursive break when in 2000 the first administration not belonging to the party in power since the 1920s took office. Thus, going further than his predecessor's the Fox administration's six-year (2000-2006) plan did not even mention nationalism; and refers only to Mexico's «national identity and culture.» (Poder Ejecutivo Federal 2007, 26). Regarding the revolution, the first president belonging to the Conservative National Action Party (PAN) would note: «In 2000, at long last, we Mexican made the ideals of the revolutionary movement effective and used our vote as the best weapon to get rid of the authoritarian regime. (Fox 2006)». Similarly, the six yearplan of the second PAN government, that of Felipe Calderón (2006-2012), pretty much ignored revolutionary nationalism as national identity. Instead, it emphasized that «Mexicans should make of pluralism our greatest strength and unite our wills and efforts to make those aspirations which make us agree and give us identity as a nation come true» (Poder Ejecutivo Federal 2007, 313). There was thus a clear break from past discourse regarding the understanding of state identity.

Interestingly, the anti-drug struggle played a less predominant role in Mexico's relationship with the United States at the turn of the century. During Fox's government cooperation on anti-narcotic matters with Washington continued, but in a less ambitious manner. Furthermore, a qualitative change was not pursued, as did occur with the intensification of the North American general integration project as enshrined in Fox's NAFTA-Plus proposal, or with the specific issue of comprehensive migratory reform - the 'whole enchilada'. The agenda was indeed dominated by the search for a migration agreement September $11^{\text {th }}, 2001$. Since that day's lethal events, security matters as defined by Washington would occupy centre stage. It may be said that since then, anti-drug cooperation, while continuing to grow, was no longer a priority, nor was it one where great efficiencies were gained. During the Fox's administration the High Level Contact Group was not convened. ${ }^{13} \mathrm{~A} 2004$ report by the

13 The final meeting for this group was held in Aug. 2000-at which, incidentally, the members called for continuity for the group during future administrations. The High Level Contact Group was replaced 
Congressional Research Service noted that the results from the cooperation between George W. Bush's and Fox's administrations on drug trafficking matters were mixed (Storrs 2004, 3).

During this period, war between drug cartels became more aggressive as they struggled to control different geographic areas. The increased level of aggression moved Washington to focus once more on the drug trade problem in Mexico. Thus, following a wave of violence on the border, in January 2005 the State Department warned US citizens about the 'serious security situation in Mexico'; simultaneously, ambassador Tony Garza wrote to Foreign Affairs Minister, Luis Ernesto Derbez, and Attorney General, Rafael Macedo, expressing his concern regarding the 'incapacity' of Mexican law enforcement forces to control violence associated with drug trade (La Jornada 2005a).The Mexican government took this criticism as interference in domestic affairs, and the Office of the President made certain clarifications, including the mandatory one, i.e.: that the 'Mexican government does not allow any judgment or assessment from external governments regarding policy actions aimed at addressing its own problems' (La Jornada 2005b).

Beyond diplomatic frictions, the fact is that when President Calderón took office, drug trafficking-and organised crime more broadly-represented a

in 2002 by the Anti-Narcotic Cooperation and Justice Group, but the latter did not have the same influence as the former. serious threat to Mexico. As president elect, in a tone which recalled that of former President Zedillo, Calderón started by saying that drug trade was probably the country's greatest threat' (La Jornada 2006). After only ten days in office, President Calderón openly declared war on drug-traffickers. After initiating military operations in six states, Attorney General Eduardo Medina Mora explained that this was the new government's answer to 'a severe problem of risk of loss of sovereignty' (La Jornada 2007a).Thus, during the first year of Calderon's administration the budget earmarked to fighting drug lords not only increased substantially (by 24 per cent compared to the last year of Fox's administration), (Iniciativa Mérida 2007,2) but also-and this is undoubtedly more consequentialthe army was involved to an unprecedented level in the 'crusade' against drug traffic. In the first week of 2007 federal armed forces were sent to the states of Baja California, Michoacán, and Sinaloa; with the expansion of these operations, the federal government embarked on what it would call the National Crusade against Delinquency, whose goal was, according to the president, to win the 'war' against organised crime (La Jornada 2007b and 2007c).

It was precisely this alarming situation that allowed intensifying cooperation in the fight against drug traffic with the U.S. In the context of a visit from President Bush to the region in March of 2007, a summit meeting 
was held in Mérida where the need to strengthen cooperation on these matters was discussed. The outcome of that process was the Mérida Initiative, announced by President Bush seven months later. The new framework for cooperation sought to strengthen the efforts in justice administration and law enforcement in both countries, as well as increasing bilateral cooperation. It should be noted that the tripartite structure (what each part should do in its jurisdiction, plus the bilateral activities) of this initiative was proposed by Mexico (Rico 2008, 11). For Foreign Affairs Ministry's Alejandro Estivill, the Mérida Initiative was 'qualitatively different from what we might have seen 15 years ago'(Interview with Estivil 2008). Effectively, the strategy included a multi-annual request by the Bush government to the US Congress, of US\$1,400 million. For former Undersecretary of Hemispheric Affairs Thomas Shannon, the inclusion of financial resources, although marginal in terms of the relative costs that the Mexican government has taken on, is symbolically important considering that 'resources are the manifestation of commitment'(Interview with Shannon 2008).

The aid focused on both the fight against drug trafficking as well as the strengthening of the justice system. The largest portion of the approved transfers consisted in equipment and technical cooperation for anti-drug trafficking pursuits, and while the cost of these is only a fraction (less than 10 percent) of what the Mexican government lays out annually in the fight against drug traffic, it is symbolic of the new concentration on joint cooperation, since the amount contributed during the first year, for example, is greater than that of the previous 12 years as a whole (Woodrow Wilson International Center 2009, 13).

But what really reveals the new perspective is the fact that for the first time Washington envisaged this problem in terms of co-responsibility; that is, there was an evident recognition-far more specific than heretofore- that the U.S. is part of the problem. This recognition appears mainly in one of the three components mentioned from the Initiative: the point related to the strengthening of justice administration and law enforcement in the U.S. The objective was, as stated by the Department of State's, Jacobson, 'to strengthen institutions on both sides of theborder'(Cuellar et al. $2008,4)$. Thus, Washington is committed to increase its efforts to remove one of the principal obstacles the country has had to face in the war against drug trafficking, according to the Mexican government: the transfer of arms which reach the drug cartels (around 90 per cent of arms confiscated from them originate in the U.S.) (Woodrow Wilson International Center 2009, 16). As Undersecretary Shannon recognised: 'We understand that while drugs move north, weapons and laundered currency move south, and that part of our southwest border strategy cannot just be fending off drugs as they're coming to the United States, that it has to be 
interdicting weapons and both currency as they move south'(Interview with Shannon 2008). Thus, in 2009 the US government presented the National Southwest Border Counternarcotics Strategy, which included a chapter on arms transfers(GAO 2009, 1).

In the context of preparing for the first visit of President Barack Obama in April 2009, Secretary of State Hillary Clinton would make a significant recognition which reflected the new status of anti-drug trafficking cooperation: 'Our insatiable demand for illegal drugs fuels the drug trade... our inability to prevent weapons from being illegally smuggled across the border to arm those criminals causes the deaths of police officers, soldiers, and civilians'(El Universal 2009). The following month the U.S Secretary of Homeland Security, Janet Napolitano, designated Alan Bersin as Border Czar-a position Bersin held for a second time, as from 1995 to 1998 he had served as Attorney General for the border. One indication of changing times: while Bersin's primary concern during his first term in this position was the question of migration, later it would be drug trafficking and arms flows. As he would admit, there was a 'change of priorities' (Proceso 2009). A sort of 'Mérida 2.0' or 'Beyond Mérida' approach got in the works in 2010, and continued into Enrique Peña Nieto's administration (2012-2018; more that US\$300 million in 2011 and almost US\$300 million in 2012 in the US budget were laid out for the new programme, whereas the Obama ad- ministration requested US\$234 million for 2013) (Interview with Feeley 2010; Seelke 2011; Reforma 2012).

What is perhaps more significant about the Mérida Initiative-regardless of the rationale for its creation or its actual impact-is the increased contact between intelligence and military services of Mexico and the United States it originated. As Defence Secretary Robert Gates noted in March 2009, 'I think we are beginning to be in a position to help the Mexicans more than we have in the past. Some of the old biases against cooperation ... between our militaries ... are being set aside' (In Deare 2009, 1).By 2011, for instance, 'fusion cells' consisting of D.E.A., C.I.A., and retired US officials, working along with Mexican counterparts in Northern Mexico and Mexico City, were operating. As Eric Olson, noted, 'this kind of collaboration would have been unthinkable five years ago'(New York Times 2011a). The change has not been easy for some high officials in Mexico, who still feel estranged from the northern neighbour. As Olson has pointed out, 'The Mexicans sort of roll their eyes and say we know it's happening, even though it's not supposed to be happening... The United States is using tools in a country where officials are still uncomfortable with those tools'(New York Times 2011b). It is thus not surprising that a tense relationship between American law enforcements officials and Mexican army personnel still prevails(New York Times 2012). 
Indeed, there was some friction between the incoming Peña Nieto administration and the United States regarding the methods US security agencies were using in Mexico, but beyond some tactical adjustments (chiefly the centralisation of cooperation management in the Ministry of the Interior), bilateral cooperation on this contentious realm has continued. As Mexico's Attorney General said in a recent visit to his counterpart in Washington: 'The bilateral cooperation brought about by the Mérida Initiative has been splendid, but the enforcement mechanisms need to be reviewed' (El Universal 2013). Thus, collaboration has continued. For instance, the US Congress appropriated funds for the Merida Initiative for the 2014 fiscal year, and US intelligence played an instrumental role in the February 2014 capture of the most wanted Mexican drug lord Joaquín "Chapo» Guzmán( Washington Post 2014). Both the unprecedented extent of cooperation in this realm of the security relationship, as well as its open discussion, seem to have become a permanent feature of Mexico-US relations.

\section{Conclusions}

The evolution of the U.S.-Mexico security agenda in the last century shows light on differences between both countries regarding these matters. The divide has of evidently been related to wider cultural (Anglo America vis-à-vis Latin-America) and material (the huge power differential between the two countries) factors. But I would argue that one item in particular goes a long way in explaining the traditionally distant relationship on security affairs: Mexico's Revolutionary Nationalism as state identity. As argued above, the post-revolutionary understanding was of great significance not only for Mexico's self-definition, political consolidation, and institutional organisation, but for the way it came to perceive world affairs-and particularly the United States as well.

There was, however, a normative structure in the making since the early nineteenth century, the Western Hemisphere Idea, which made the commonality of values and interests to become evident in some particular junctures. Thus, in the 1940s (in the context of WWII), two decades later (in the triangular Cuba-Mexico-U.S. relationship), and since the late 1990s, but particularly since 2007 , in the fight against drug trafficking, bilateral cooperation on a variety of aspects of the broader security agenda has taken place.

After over 100 years since the start of the armed conflict from which a new state emerged, revolutionary nationalism as state identity has unfolded to the point of it being now pretty much gone. Accordingly, not only the change in cooperation in discrete security matters with the United States has become more evident, but it would also seem that the various components of the security agenda had started adding up. This has been particularly noticeable 
in the ongoing cooperation to combat drug trafficking, which has had a clear spillover effect on the broader security agenda. Furthermore, bilateral cooperation on this matter not only points to an unintended effect but also shows the malleability of issues. That is, partnership on what for Mexico amounted still in the mid of the first decade of the twenty-first century to a domestic national security threat-even if many of the factors behind it were external-led to an unprecedented level of cooperation with Washington on security affairs. At this point, both drug trafficking and security issues more broadly defined intermingled, with the former moving up (from low to high politics) in the bilateral agenda. The irony should be evident: the catalyser for bilateral cooperation on security matters was an issue that threatened Mexico's internal security-the kind of threat the security agenda associated with Revolutionary Nationalism privileged. However, it would seem that with the emergence of a more open, plural and democratic Mexico, Revolutionary Nationalism navel-gazing approach to security affairs has been overcome, and a kind of security in parts with the United States has emerged.

\section{REFERENCES}

Abdelal, Rawi, Yoshiko M. Herrera, Alastair Iain Johnston, and Rose McDermott. (2006) Identity as a Variable. Perspectives on Politics 4 (4): 695-711.
Aguilar Camín, Héctor. (1993). La invención de Mexico: notas sobre nacionalismo e identidad nacional. Nexos 187: 49-61.

Andreas, Peter. (1998). The Political Economy of Narco-corruption in Mexico. Current History, April: 160-165.

Archives of the State Department (1961a) Memorandum from Edward G. Cale, Chargé d'Affaires ad interim to Thomas C. Mann, Assistant Secretary of State for Inter-American Affairs. American Embassy, Mexico D. F., 14 February 1961, 3.

Archives of the State Department (1961b) "The tactical handling of relations with Mexico». American Embassy, 14 February 1961,6 .

Archives of the U.S. State Department (1956) Memorandum of Conversation between Eisenhower, Ruiz Cortines, and Lt. Colonel Vernon A. Walters. 27 March 1956, 3.

Archives of the U.S. State Department (1962) Presidential Memorandum of Conversation on Communism in Latin America. Lot 66 D149. Kennedy, López Mateos, Tello, Mann, Martin, Carrillo Flores. 29 June 1962 [written 3 July], 2.

Archivo Histórico Diplomático (1941) Diplomatic Historical Archive) .Manuel Ávila Camacho, Mexico y la guerra en el Pacifico.

Archivo Histórico Diplomático (1947) Respuesta de Alemán a discurso de bienvenida de Truman a Washington el 29 de abril de 1947. Mexico: Secretaría de Relaciones Exteriores.

Bárcena Coqui, Martha. (2003). Mexico y Estados Unidos en el contexto internacional y sus intereses de seguridad nacional. In La seguridad nacional en las relaciones Mexico-Estados Unidos, edited by A. Maciel. San Luis Potosí: El Colegio de San Luis: 15-31.

Bartra, Roger. 1989. La crisis del nacionalismo en Mexico. Revista Mexicana de

Sociología 51 (3): 191-220.

- (1991). La venganza de la Malinche: hacia una identidad postnacional. Este País (1). 
Benitez Manaut. (2008). La seguridad nacional en la indefinida transición: mitos y realidades del sexenio de Vicente Fox. Foro Internacional 191-192: 184-208.

___ (1998). Soberanía, política exterior y seguridad nacional en Mexico: 18211990. Revista Mexicana de Administración Pública, INAP, vol. Seguridad Nacional: 57-78.

Bow, Brian and Arturo Santa-Cruz. (2011). Diplomatic Cultures: Multiple Wests and Identities in US-Canada and US-Mexico Relations. In Peter J. Katzenstein (ed.) Anglo-America and its Discontents, Civilizational identities beyond West and East. New York: Routledge.

Breuilly, John. (1985) Reflections on Nationalism. Philosophy of the Social Sciences 15 (1).

Castañeda, Jorge. (1969). Revolution and Foreign Policy: Mexico's Experience. In C. A. Astiz (ed) Latin American International Politics: Ambitions, Capabilities, and the National Interest of Mexico, Brazil and Argentina. Notre Dame: University of Notre Dame Press: 137-165.

Castañeda, Jorge and Robert Pastor. (1989). Limites en la amistad Mexico y Estados Unidos. Mexico: Joaquín Mortiz/Planeta.

Comisión para el futuro de las relaciones Mexico-Estados Unidos. (1988). El desafío de la interdependencia. Mexico: Fondo de Cultura Económica.

Concepción Montiel, Luis Enrique. (2006). El discurso presidencial en Mexico: el

Sexenio de Carlos Salinas de Gortari. Mexico: Universidad Autónoma de Baja

California-Miguel Ángel Porrúa.

Curzio, Leonardo. (2007). La seguridad nacional en Mexico y la relación con Estados Unidos. Mexico: UNAM-CISAN.

Cope, John A. (1997). En busca de la convergencia: las relaciones militares entre

Mexico y Estados Unidos en el umbral del siglo XXI. In S. Aguayo

Quezada and J. Bailey Las seguridades de Mexico y Estados Unidos en un momento de transición. Mexico: Siglo XXI Editores: 231-270.
Cuellar, Henry et al. (2008). Five Perspectives on the Merida Initiative: What it is and Why it Must Succeed. American Enterprise Institute for Public Policy Research, March, 1: 1-7.

Deare, Craig A. (2009). U.S.-Mexico Defense Relations: An Incompatible Interface. Strategic Forum. Institute for National Strategic Studies, National Defense University, July (243).

Diplomatic Historical Archive (n.d) Francisco Castillo Nájera, Mexico Does its Part.

Downie, Richard D. (2011). Critical Strategic Decisions in Mexico: The Future of

US/Mexican Defense Relations. Strategic Issues in US/Latin American Relations 1 (1).

Dziedzic, Michael J. (1994). Mexico. In D. J. Murray and Paul R. Viotti (eds) The Defense Policies of Nations: A Comparative Study. Baltimore and London: The Johns Hopkins University Press: 110-142.

El Informador (1946) Discurso del Licenciado Miguel Alemán. 24 January.

El Universal (2000) Estima Davidow que el país será certificado. 22 February.

El Universal (2009) Hilary: injusto culpar a Mexico por el narco, 26 March.

El Universal (2013) Mexico plantea a Estados Unidos revisar aplicación de Iniciativa Mérida, 10 September.

Engel, James F. (1969). The Revolution and Mexican Foreign Policy. Journal of InterAmerican Studies 11 (4): 518-532.

Enciso, Froylán. (2009). Drogas, narcotráfico y política en Mexico: protocolo de hipocresía (1969-2000). In I. Bizberg and L. Meyer (eds) Una historia contemporónea de Mexico. Tomo 4: Las políticas. Mexico: Océano-Colegio de Mexico.

Erfani, Julie A. (1995). The Paradox of the Mexican State, Rereading Sovereignty from Independence to NAFTA. Boulder: Rienner.

Estivill, Alejandro. (2008). Interview with the author, Mexico City, 3 July.

Feeley, John D. (2010). interview with the author, Mexico City, 19 April.

Fox, Vicente. (2007). Palabras del Presidente Vicente Fox Quesada, durante la Cer- 
emonia del XCVI Aniversario del Inicio de la Revolución Mexicana, que tuvo lugar en esta ciudad. Avalaible at http:// fox.presidencia.gob.mx/actividades/ orden/?contenido $=28283$

Gall, Olivia. 2004. Identidad, exclusión y racismo: reflexiones teóricas y sobre Mexico. Revista Mexicana de Sociología 66 (2): 221-259

GAO. (2009). Firearms Trafficking: U.S. Efforts to Combat Arms Trafficking to Mexico Face Planning and Coordination Challenges. Washington: GAO.

González G, Guadalupe. (2003). Los dilemas de la cooperación bilateral en el combate contra el narcotráfico. In Agustín Maciel (ed) La seguridad nacional en las relaciones Mexico-Estados Unidos. San Luis Potosí: El Colegio de San Luis: 263-283.

Haglund, David. (1984). Latin America and the transformation of U.S. strategic thought, 1936-1940. Albuquerque: University of New Mexico Press.

Herrera-Lasso, Luis and Jorge Tello Peón. (2011). Pasado y presente de las amenazas externas a la seguridad nacional de Mexico. In Guadalupe González and Olga Pellicer (eds) Los retos internacionales de Mexico: urgencia de una mirada nueva. Mexico: Siglo XXI: 255-300.

Historic Diplomatic Archives (1942) Memorandum from Castillo Nájera to the Secretary of Foreign Relations, Washington, D. C., 12 January 1942.

Historic Diplomatic Archives (1967) Letter from the Mexican Ambassador in Cuba (Fernando Pámanes) to the Foreign Relations Secretary 12 April 1967.

Katzenstein, Peter J. (1996) Introduction: Alternative Perspectives on National Security. In P. J. Katzenstein (ed) The Culture of National Security: Norms and Identity in World Politics. New York: Columbia University Press.

Kratrochwil. Fredrich (2008) Sociological Approaches. In The Oxford Handbook of International Relations, edited by C. ReusSmit and D. Snidal. New York: Oxford University Press.
Knight, Alan. (2006). ¿Relaciones especiales? Una comparación de las relaciones Gran Bretaña-Estados Unidos y Mexico-Estados Unidos. In Rafael Fernández de Castro, Laurence Whitehead and Natalia Saltalamacchia (eds) ¿Somos especiales? Las relaciones de Mexico y Gran Bretaña con Estados Unidos: una visión comparada. Mexico: ITAM, COMEXI: Porrúa: 21-53.

___ (2000). Cómo lidiar con el sistema político estadounidense: una visión histórica 1910-1995. In R. de la Garza and J. Velasco (eds) Mexico y su interacción con el sistema político Estadounidense. Mexico: CIDE/Miguel Ángel Porrúa: 23-73.

----. (2009). El gen vivo de un cuerpo muerto. Nexos (383): 25-26.

Kowert, Paul. 2007. National Identity: Inside and Out. Security Studies 2 (3): 1-34.

La Jornada (2005a) "'Seria inseguridad' en Mexico, advierte EU», 27 January.

La Jornada (2005b) Mexico no admite juicios externos sobre su política, responde Los Pinos. 28 January.

La Jornada (2007a) Las extradiciones de narcos no generarán una ola de violencia, asegura Medina Mora. 24 January.

La Jornada (2007b) Miles de fuerzas federales en el operativo Tijuana. 3 January.

La Jornada (2007c) Ofrece Calderón ganar la guerra al crimen organizado. 23 January.

La Jornada Aranda, Jesús and José Antonio Román (2006) Seguridad, obligación del Estado:Calderón. 26 October.

Langenbacher, Eric. (2010) Collective Memory as a Factor in Political Culture and International Relations. In Langenbacher and Y. Shain (eds) Power and the Past: Collective Memory and Inter- national Relations. Washington, D.C.: Georgetown University Press.

LBJ Library Archives (1964a) Memorandum of Conversation between Johnson, Diaz Ordaz and Carrillo Flores. LBJ Ranch, Texas. 12 November 1964, 3.

LBJ Library Archives (1964b) Meeting of Presidents Johnson and López Mateos in California. Talking Points: U. S.-Mexican 
Arturo Santa Cruz • La evolución de la agenda de seguridad México-Estados Unidos

Cooperation on Cuba (To be raised by President). February 20-22, 1964.

Legro J.W. 2009. The Plasticity of Identity under Anarchy. European Journal of International Relations 15 (1): 37-65.

Lomnitz, Claudio. (2010). Por mi raza hablará el nacionalismo revolucionario (Arqueología de la unidad nacional). Nexos (386).

Lopez, Rick. (2010). Crafting Mexico: Intellectuals, Artisans, and the State after the Revolution. Durham: Duke University Press.

McSweeney, B. 1999. Security, Identity, and Interests: A Sociology of Interna-tional Relations. Cambridge: Cambridge University Press.

Mexico-United States (1941). The American Jorunal of International Law, 53 (4). Supplement Official: 201-203.

Meyer, Lorenzo. (2000). La Marca del Nacionalismo. Mexico: El Colegio de Mexico/ Senado de la República.

Monsiváis, Carlos. (1976). Notas sobre la cultura mexicana en el siglo XX. In Historia General de Mexico. Mexico: Colegio de Mexico.

Morley, Jefferson. (2008). Our Man in Mexico. Winston Scott and the Hidden History of the CIA. Lawrence: University Press of Kansas.

National Security Archive, GWU (1964) Document 2. Your Meeting with President López Mateos. Secretary of State. 18 February 1964. The Nixon Tapes, 21.

National Security Archive, GWU (1967).U.S. embassy's chargé d'Affaires Henry Dearborn in a cable to the State Department. May 1967.The Nixon Tapes, 14.

National Security Archive, GWU (1972) The Nixon Tapes (11). Conversation (735-1) between Nixon, Echeverría, Alexander M. Haig, Jr. And translator Donald F. Barnes. 15 June 1972.

New York Times (1960) Mild Policy Asked for U.S. on Cubans. 14 August.

New York Times (1962) Texts of U.S.-Mexican Communique and Kennedy Statement. 1 July.
New York Times (2011a) U.S. Widens Role in Mexican Fight. 25 August.

New York Times (2011b) U.S. Infiltrating Criminal Groups Across Mexico: [Foreign Desk]. 25 October: E42.

New York Times (2012) Adding to Unease of a Drug War Alliance,» in 29 May.

Ojeda, Mario. (2006). Alcances y Limites de la Política Exterior de Mexico. Mexico: Colegio de Mexico. - (1966). The Role of Mexico as a Middle Power. In J.K. Gordon (ed) Canada's Role as a Middle Power. Toronto: The Canadian Institute of International Affairs.

Pastor, Robert, (2008) interview with author, Washington, D. C., 28 July.

Paz, María Emilia. (1998). Strategy, Security, and Spies: Mexico and the U.S. as Allies in World War II. University Park: The Pennsylvania State University Press.

Poder Ejecutivo Federal. (1995).Plan Nacional de Desarrollo 1995-2000. Ciudad de Mexico, Presidencia de la Republica.

Poder Ejecutivo Federal. (1995). Plan Nacional de Desarrollo 1995-2000. Ciudad de Mexico, Presidencia de la Republica.

Poder Ejecutivo Federal. (2007). Plan Nacional de Desarrollo 2007-2012. Ciudad de Mexico, Mexico.

Proceso (2009) Descarta EU construir más muros en la frontera con Mexico, 16 April.

Reforma (2012) Pide Obama 234 mdd para Mexico en 2013. 13 February.

Rico, Carlos. (2008). La Iniciativa Mérida y el combate nacional al crimen organizado. Foreign Affairs en Español 8 (1): 3-13.

Rojas, Rafael and Ana Covarrubias. (2011) Historia de las relaciones internacionales de Mexico, 1810-2010: Caribe. Mexico: Secretaría de Relaciones Exteriores.

Ruiz-Cabañas (1998) Intereses contradictorios y mecanismos de cooperación: el caso del narcotráfico en las relaciones mexicano-estadounidenses. In Mexico $y$ Estados Unidos: las rutas de la cooperación, compiled by Olga Pellicer and Rafael Fernández de Castro. Mexico: SRE-ITAM: 101-134. 
Santa-Cruz, Arturo (2005) Constitutional Structures, Sovereignty, and the Emergence of Norms: The Case of International Election Monitoring. International Organization59: 663-693.

Secretaría de la Defensa Nacional (1979) El Ejército mexicano. Mexico: Secretaría de la Defensa Nacional.

Security. FF17B. (1942) Memorándum Confidencial de Ezequiel Padilla a Francisco Castillo Nájera. Mexico D.F., 12 de Junio, 2.

Senate Foreign Relations Committee and Senate Caucus on International Narcotics Contro, Joint hearing of (1997) U.S. and Mexican Counterdrug Efforts since Certification, 105th Cong., 1st session, 29 October 1997 (from: http://drugcaucus. senate.gov/hearingpast.html).

Sepúlveda Amor, Bernardo (1994) Los intereses de la política exterior. In La política internacional de Mexico en el decenio de los ochenta, compiled by César Sepúlveda. Mexico: Fondo de Cultura Económica: 17-71.

Serrano, Mónica (2007) Mexico: narcotráfico y gobernabilidad. Pensamiento Iberoamericano 1 (1): 251-278.

Schulz, Donald E. (1997) Between a Rock and a Hard Place: The United States, Mexico, and the Agony of National Security. SSI Special Report, 24 June.

Seelke, Clare R. (2011) Mexico Issues for Congress. Congressional Research Service.

Shannon, Thomas (2008) Interview with the author, Washington, D. C., 25 July.

Smith, Anthony D. 1998. Nationalism and Modernism. London: Routledge.

Storrs, K. Larry. (2004) Mexico's CounterNarcotics Eff orts under Fox, December 2000 to October 2004. Congressional Research Service Report for Congress.

State Department Archives (1955) Letter from Francis White (American Embassy) to the White House. Mexico, D. F., 29 August 1955, 2.

State Department Archives (1965) Telegram from the American Embassy in Mexico to the Secretary of State. 2 March 1965.
Subotic, Jelena. 2011. Europe Is a State of Mind: Identity and Europeanization in the Balkans. International Studies Quarterly 55 (2).

Tello, Manuel. (1975) La política exterior de Mexico (1970-1974). Mexico: Fondo de Cultura Económica.

The Nixon Tapes (n.d) Secret Recordings from the Nixon White House on Luis Echeverría and Much Much More (http://www.gwu.edu/ nsarchiv/NSAEBB/ NSAEBB95/).

Torres, Blanca. (1979) Historia de la Revolución Mexicana: Periodo 1940-1952: Mexico en la Segunda Guerra Mundial. Mexico: El Colegio de Mexico.

Toro, Celia. (1998) Estrategias mexicanas de negociación: el caso del narcotráfico. In Mexico ante el fin de la Guerra Fría, compiled by Ilán Bizberg. Mexico: El Colegio de Mexico: 323-337.

Treverton, Gregory F. (1989) Los narcóticos en la relación de Mexico y Estados Unidos. In Mexico y Estados Unidos: el Manejo de la relación, compiled by Riordan Roett. Mexico: Siglo XXI Editores: 277-294.

Velasco Márquez, Jesús. (2006) La relación especial de Mexico y Estados Unidos: una realidad no reconocida. In Rafael Fernández de Castro, Laurence Whitehead and Natalia Saltalamacchia (eds) ¿Somos especiales? Las relaciones de Mexico y Gran Bretaña con Estados Unidos: Una visión comparada. Mexico: ITAM, COMEXI, Porrúa: 77-94.

U. S. Department of State (1972) Papers Relating to the Foreign Relations of the United States 1948, vol. 9. Washington: United States Government Printing Office.

U.S. Department of State. (1983) Papers Relating to the Foreign Relations of the United States 1952-1954, vol. 4. Washington, D.C.: United States Government Printing Office.

Victoria, Guadalupe. (1986) Guadalupe Victoria: correspondencia diplomática. Mexico: Secretaría de Relaciones Exteriores.

Waltz, K. N. 1979. Theory of International Politics. New York: McGraw-Hill. 
Arturo Santa Cruz • La evolución de la agenda de seguridad México-Estados Unidos

Washington Post (2014) U.S. and Mexican authorities detail coordinated effort to capture drug lord. 23 February.

Wendt, Alexander. 1999. Social Theory of International Politics. Cambridge: Cambridge University Press.

Werner, W. G. and J. H. De Wilde. 2001. The Endurance of Sovereignty. European Journal of International Relations 7 (3): 283-313.

Whitaker, A. P. (1954). The Western Hemisphere Idea: Its Rise and Decline. Ithaca: Cornell University Press.

Whitaker, A. P. (1954). The Western Hemisphere Idea: Its Rise and Decline. Ithaca: Cornell University Press.

Woodrow Wilson International Center for Scholars; Mexico Institute. (2009) The
United States and Mexico: Towards a Strategic Partnership. A Report of Four Working Groups on U.S.-Mexico Relations. Washington, D.C.: Woodrow Wilson International Center for Scholars; Mexico Institute.

Woolley, John T. and Gerhard Peters (n.d) The American Presidency Project, Santa Barbara, CA: University of California, Gerhard Peters (found at www.presidency. ucsb.edu/ws/?pid=58841).

Zorrilla, Luis G. (1965) Historia de las Relaciones entre Mexico y los Estados Unidos de América (1800-1958). Tomo 2. Mexico: Porrúa. 